ساهرة فليح محمد ظاهر (1)

تأريخ تقديم البحث: (2021/5/25)، تأريخ قبول النشر (2021/6/28)، تأريخ النشر (2021/9/28) DOI: https://doi.org/10.37359/10.37359/JOPE.V33(3)2021.1190

\title{
المستخلص
}

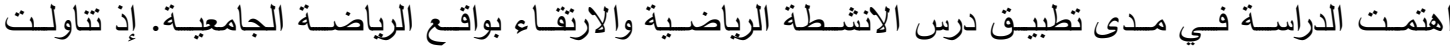
مشـكلة الدراسـة قلـة المحـاولات لتحسـين مسـتوى الرياضــة الجامعيـة، لـذا سـعت الباحثـه إلىى ضـرورة إخضــاع المـهـج المعـد مـن قبـل قسـم النشـاطات الطلابيـة / جامعـة بغـداد، عبـر التحليـل الاسـتراتيجي، وبــللك يهـدف البحـث إلـى التعـرف علـى نتـائج التحليـل الاسـتراتيجي لتقـويم درس الانثــطة الرياضـية، ومــا الفـروق بـين الكليـات العلميــة و الكليات الانسانية ودورهـا في الانشطة الرياضية. واعتمدت العينـة تمثل مجتمع البحث في العاملين ( تدريسين،

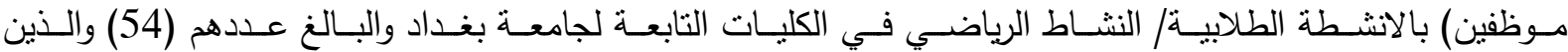

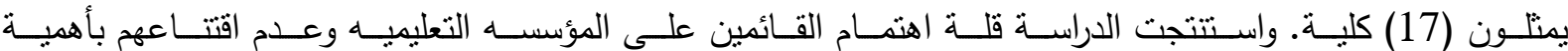
الانثـطة الرياضــية فـي العمليـة التعليميـة. والمعوقـات الاداريـة تعيـق الطلبـهـ مـن المشـاركة بالانثـطة الرياضـية.

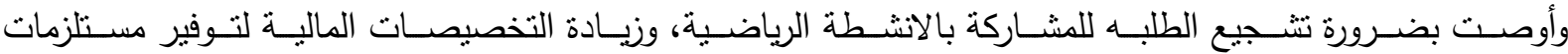
النشاط الرياضي من قبل الجامعة. الكلمات المفتاحية: التحليل الاستراتيجي، التقويم، النشاطات الرياضية الطلابية، الرياضة الجامعية.

\section{ABSTRACT \\ Strategy Analyses Study For Evaluating Sport Activities on University of Baghdad Colleges}

The research aimed at identifying the results of strategic analyses for evaluating sport activities as well as identifying the differences between scientific and humanity colleges and their role in sport activities. The subjects were (54) faculty members in students activity/ sport activities in (17) colleges affiliated to the university of Baghdad. The results showed lack of interest in sport activities as well as administrative obstacles that hinder students' participation in sport events. Finally the researcher recommended the necessity of encouraging students to participate in sport activities and increasing the university's financial support.

Keywords: strategy analyses, evaluation, students sport activities, University Sport.

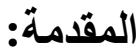

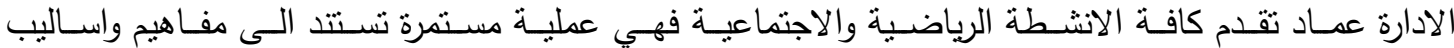

علميـه تهـدف الـى تحقـق نتـائج جيـدة باسـتخدام المـوارد المتاحـة والهيئـات الرياضـية و ذلـك مرهـون بمـدى اسـتخدام

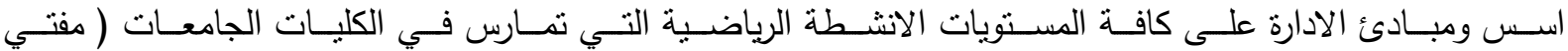




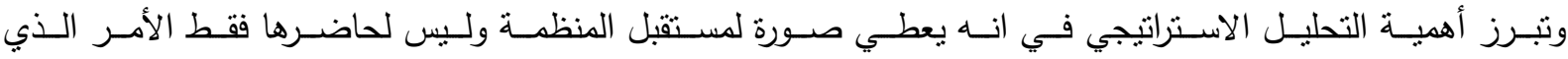
يسـاعد على وضـع خطط وبـدائل اسـتراتيجية تاخـذ بنظـر الاعتبـار توقعـات التغيـرات البيئـة المحتملـة ومـدى امكانيـة

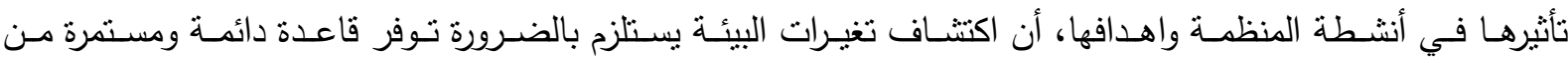
المعلومـات إذ أن أخطر مـا يواجـه المنظمـات اليوم هـو الفهم غيـر الصـحيح والمتقـادم للبيئـة مـن لـدن الأدارة العليـا (صالح احمد: 2015: 321-323).

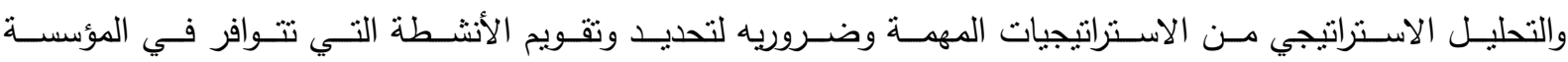

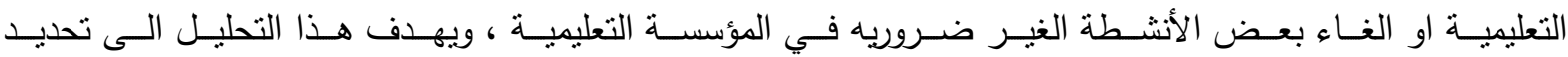

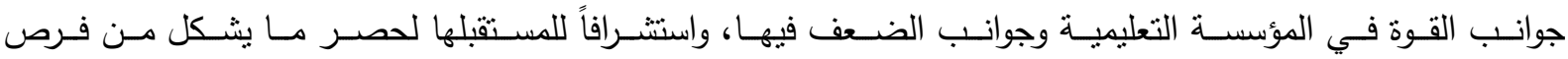
وعقبات محتملة تمهيدا لاختيار المسار الذي يؤمن الاستثمار الامتل لها.

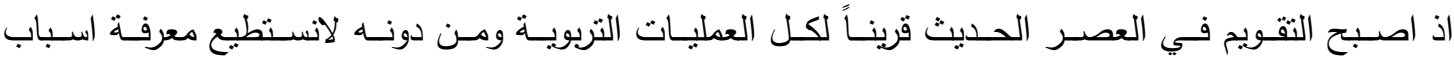

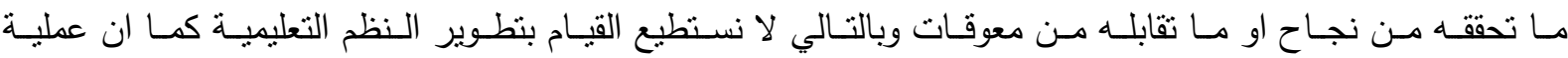

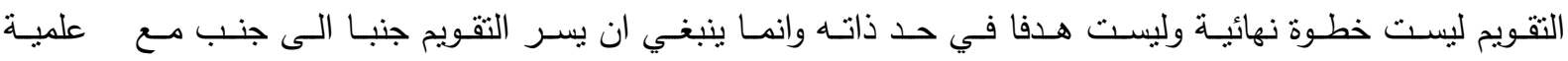
التخطبط والتظظيم وتتفيذ المهام (علي البيك: 197:1993)

وتعتبـر الانشـطة الرياضـية نشـاط ترويحسي يحظـى باهتمـام الطلبـة و يثيــر انتبـاههم اكتـر مـن اي شـيء

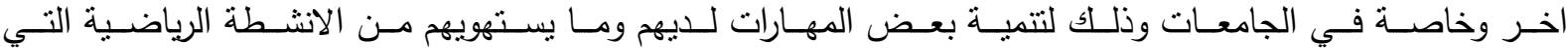

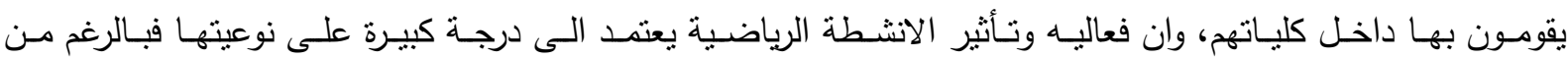

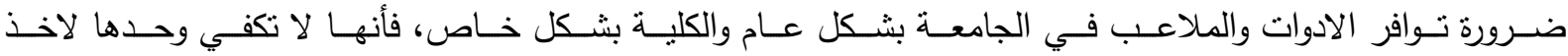

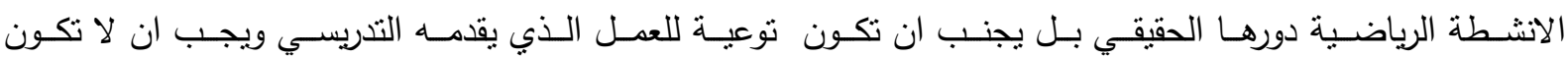
الانثـطة الرياضـية غايـة بحـد ذاتها بـل يجـب ان تكسون محفزأ لاسـتمرار المهـارات التي يكتسـبها الطلبـه، والاسـتفادة منها في اوقات فراغه.

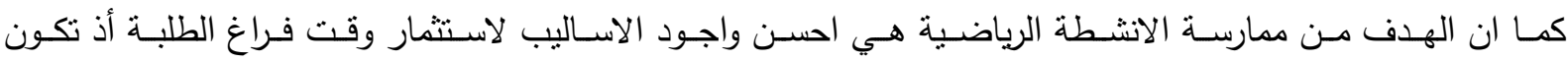
مناسـبة لهوايـاتهم وميـولهم الثخصـية وهـي بالتـالي عوامـل مهــة لتطـوير وتكامـل شخصـياتهم أذ نسـهم لحـــ كبيـر في انمـاء صـفة القيـادة المبكرة والسـوك الطيـب كالتعـاون والتشـامح والايثـار اضـافة الـى اكتسـابهم الخبـرة والمهـارة الفنية الجيدة (قاسم واخرون: 1979: 86). وبنـاءاً على مـا سـبق تبـرز أهميـة البحـث كونـهـ محاولـة جـادة للتعـرف على مـدى تطبيـق درس الانثـطة

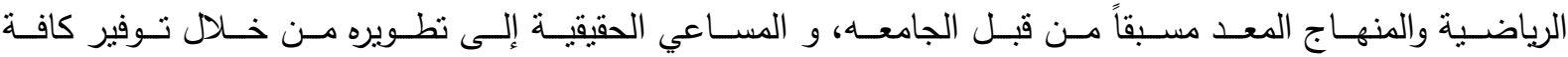

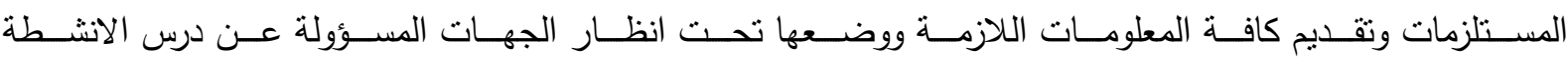
الرياضية في الجامعه، كخطوة مهمة للارتقاء بواقع الرياضة الجامعية وتحقيق الأهداف التعليمية والتربوية.

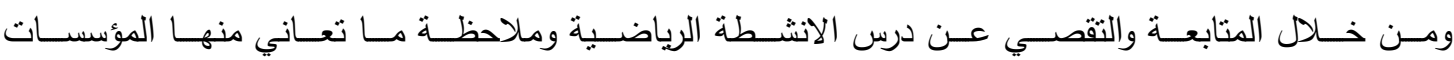

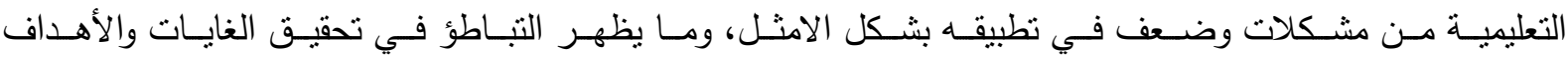

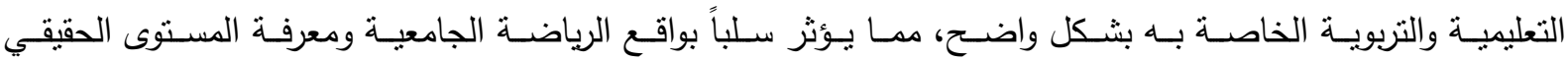




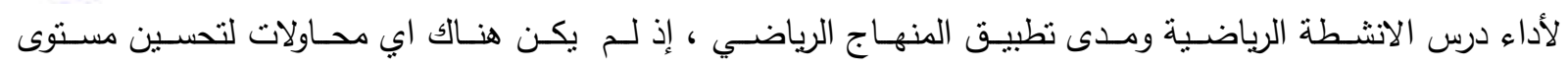

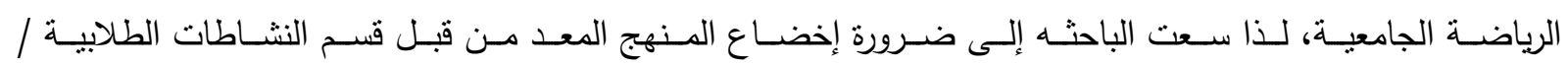
جامعــة بغـداد، عبـر التحليـل الاسـتراتيجي، وبـذللك يهـدف البحـث إلـى التعـرف علـى نتـائج التحليـل الاسـتراتيجي

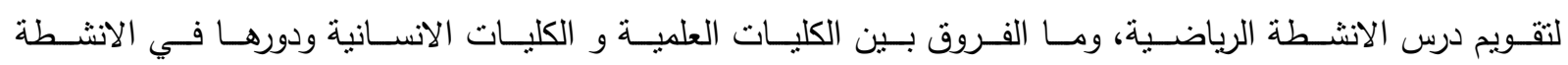
الرياضبة.

\section{الطريقة والادوات: - مبة}

استخدمت الباحثة المنهج الوصفي بالأسلوب المسحي والعلاقات الأرتباطية لملائمته طبيعة البحث، هو

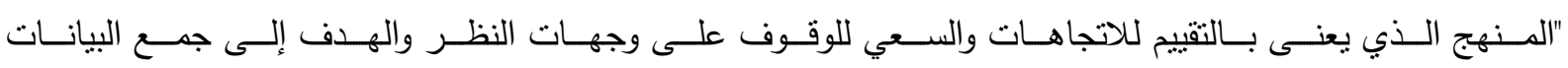
الديمغرافية عن الأفراد، أو ترمي إلى التعرف على الظروف العمل ووسائله"(الكاظمي: 2012: 117).

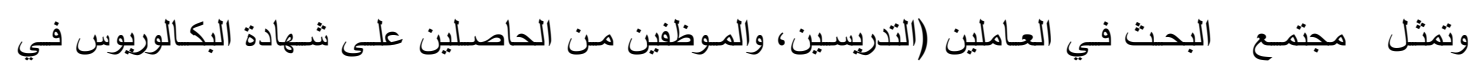
التربيـة البدنيـة وعلـوم الرياضـية) بالانشــة الطلايبـة/ النشـاط الرياضـي في الكليـات التابعـة لجامعـة بغــاد مـا عـدا

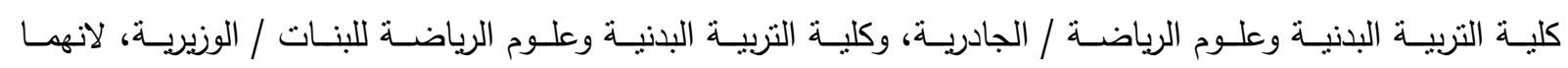

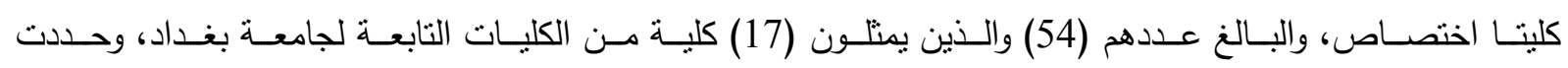
الباحثة المجتمع ككل عينة للبحث. اذ قامت الباحثة بأستعمال استمارة الاستبيان لجمع البيانات و المعلومات بعد للأجابة عليها من قبل عبنة البحث، وكذلك قامت بأجراء المقابلات الثخصية، وبمساعدة فريق العمل المساعد . الجدول (1) يبين نوزيع عينة البحث

\begin{tabular}{|c|c|c|}
\hline 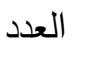 & الكلية & $ت$ \\
\hline 3 & الطب & 1 \\
\hline 3 & طب الاسنان & 2 \\
\hline 2 & الصيدلة & 3 \\
\hline 4 & 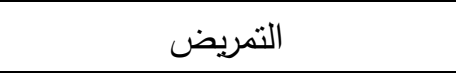 & 4 \\
\hline 3 & الطب البيطري & 5 \\
\hline 2 & الهندسة & 6 \\
\hline 2 & الهندسة خوارزمي & 7 \\
\hline 4 & 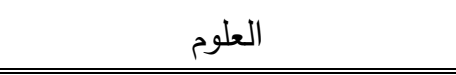 & 8 \\
\hline 5 & العلوم للبنات & 9 \\
\hline 3 & التزبية للبنات & 10 \\
\hline 3 & التربية للعلوم الانسانية/ ابن الرثد & 11 \\
\hline 2 & اللغات & 12 \\
\hline 4 & 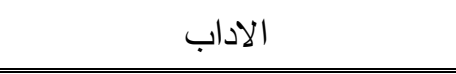 & 13 \\
\hline 5 & القانون & 14 \\
\hline
\end{tabular}




\begin{tabular}{|c|c|c|}
\hline 3 & الادارة و الاقتصاد & 15 \\
\hline 2 & كلية الهندسه وعلوم الزراعة & 16 \\
\hline 4 & التربيه للعلوم الصرفه/ابن الهيثم & 17 \\
\hline 54 & المجموع & \\
\hline
\end{tabular}

أداة البحـث: بعد اطـلاع الباحثة على الادبيـات العربيـة والأجنيبـة التي تتاولت متغيـر البحث للوقوف على كافـة النتائج التـي تـم التوصـل إليهـا مـن خـلال البحـوث السـابقة في الجـانبين النظـري والعملـي، ولتحقيـق أهـاف البحــ

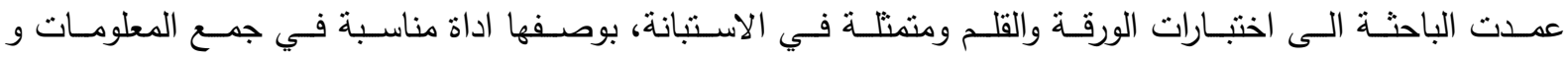

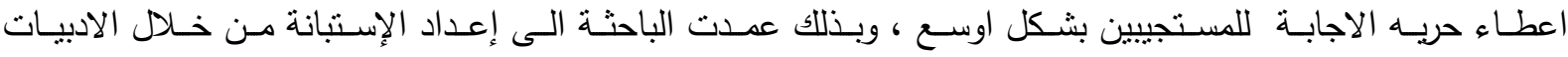
و واقـع الانثـــة الرياضــية فـي ضـوء التحليـل الاسـتراتيجي. وقامـت الباحثـة بـإجراء بعـض المقـابلات الثخصـية والزيارات الميدانية للوقوف على واقع الانشطة الرياضية. خطوات إعداد الإستبانة :

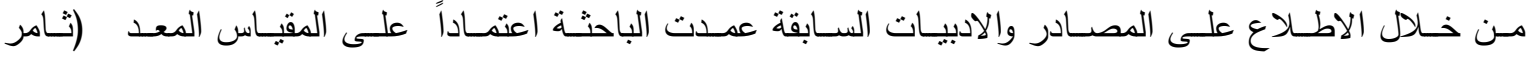
حـــاد: 2018: 17) مـن خـلال إعـداد(4) محسـاور الرئيسـة للاسـتبانة تمثـل اتجاهـات التحليـل الاسـتراتيجي وهـي (القـوة ، والفـرص، والضـعف، والتهديـدات)، والتعـديل عليهـا مـع وضـع التعريفـات النظريـة لكـل محـور، وعرضـهـا على الخبـراء والبـالغ عـدهم (9) خبـراء، وحصـلت على موافقـة بنسـبة (100\%)، ومـن ثم حددت الباحثـة مجموعـة مـن الفقرات لكـل محسور بحسـب مـا ارتـأت الباحثنة، إذ حـد (34) فقرة موزعـة على المحساور الاربعـة الرئيسـة، مـن

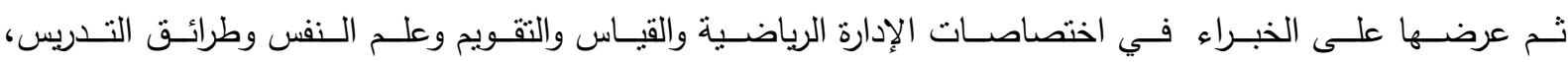
للأخــ بـآرائهم فـي صــلاحية الفقـرات، وعمــت الباحثـة الـى اسـتخدام طريقـة ليكـرت (Likert) في احتسـاب اوزان الفقـرات بوصـفه أكثتر المقـاييس اسـتخداماً للبحــوث المسـحية للعبـارات ذات الإجابـات المغلقـة، فضــلاً عـن حريـة

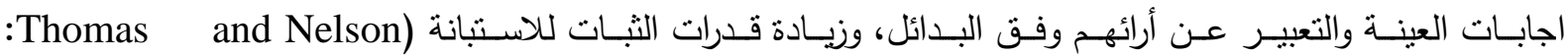

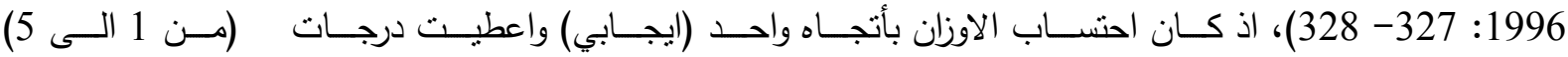
للبـدائل (تتطبـق بدرجـة قليلــة جـداً، تتطبـق بدرجـة قليلـة، تتطبـق بدرجـة منوسـطة، تتطبـق بدرجـة كبيـرة، تتطبـق بدرجة كبيرة جداً) وعلى التوالي. المعاملات العلمية للاستبانة:

الصـدق الظـاهري: وهـو مـن اهم انـواع الصـدق ويشـير الـى مدى صـلة الفقرة بالظـاهرة المـراد قياسـها، وقد

تحقق الصـدق الظـاهري للاستبانه عندما تم عرض الاستبانه على مجموعـة مـن الخبراء وعددهم (9) خبـراء للحكم على مـدى صـلاحية مجـالات وفقرات الاسـتبانه في قيـاس التحليـل الاسـتراتيجي، وكانـت نسـبة اتفـاقهم .$(\% 100)$ القـوة التمييزيـة: قامـت الباحثـة باسـتخراج الدرجـة الكليـة لكـل مسـتجيب علـى الاسـتبانه البـالغ عـددها (54)، وترتيبهـا تصـاعدياً، بعدها تـم إسـتخراج القوة التميزيـة عـن طريـق إسـتخدام الإختبـار التـائي (t.test) ) لدلالـة

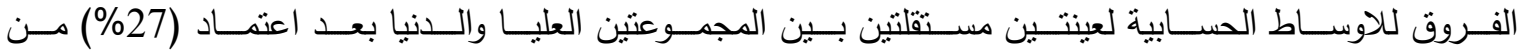




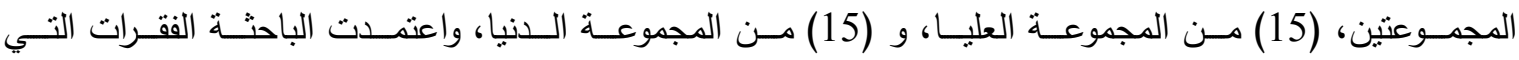

قيمة الدلالة لها هو اقل من مستوى الدلالة المعتمد (0.05) ولدرجة حرية (28).

الجدول (2) يبين القوة التمييزية لفقرات الاستبانه

\begin{tabular}{|c|c|c|c|c|c|c|c|}
\hline \multirow{2}{*}{ النتيجة } & \multirow{2}{*}{ قالدالة } & \multirow{2}{*}{ قيمة(t) } & \multicolumn{2}{|c|}{ المجموعة العليا } & \multicolumn{2}{|c|}{ المجموعة الدنيا } & \multirow{2}{*}{ الاستبانة } \\
\hline & & & $\varepsilon$ & س & $\varepsilon$ & س & \\
\hline معنوي & 0.000 & 9.644 & 18.51589 & 131.1333 & 18.39979 & 66.1333 & الاستراتيجي \\
\hline
\end{tabular}

قيمة الدلالة تكون معنوية إذا كانت > من 0.05

معامل الاتساق الداخلي: استخدمت الباحثة الأتساق الداخلي لتحقيق ذلك:

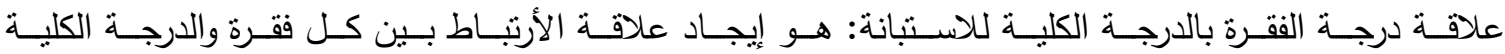
للاسـتبيان لكـل افـراد العينـة، الغـرض مـن هـذا الأجـراء هـو ارتبـاط درجـة الفقـرة بالدرجـة الكليـة للمقيـاس الحـالي

اذ ان الفقرة تمنل المفهوم او السمة المراد قياسها.

الجدول (3) يبين معامل الإرتباط بين درجة الفقرة والدرجة الكليةلاستبيان التحليل الاستراتيجي

\begin{tabular}{|c|c|c|c|c|c|c|c|}
\hline النتيجة & قيمة الدلالة & معامل الإرتباط & رقم الفقرة & النتيجة & قيمة الدلالة & معامل الإرتباط & رقم \\
\hline معنوي & 0.000 & $.705^{* * *} 0$ & 18 & معنوي & 0.000 & $.591^{* *} 0$ & 1 \\
\hline معنوي & 0.000 & $.557^{* *} 0$ & 19 & معنوي & 0.000 & $.586^{* *} 0$ & 2 \\
\hline معنوي & 0.000 & $.738^{* * *} 0$ & 20 & معنوي & 0.000 & $.701^{* *} 0$ & 3 \\
\hline معنوي & 0.000 & $.645^{* *} 0$ & 21 & معنوي & 0.000 & $.603^{* *} 0$ & 4 \\
\hline معنوي & 0.000 & $.705^{* * *} 0$ & 22 & معنوي & 0.000 & $.595^{* *} 0$ & 5 \\
\hline معنوي & 0.000 & $.671^{* * *} 0$ & 23 & معنوي & 0.000 & $.705^{* *} 0$ & 6 \\
\hline معنوي & 0.000 & $.699^{* *} 0$ & 24 & معنوي & 0.000 & $.754^{* *} 0$ & 7 \\
\hline معنوي & 0.000 & $.668^{* *} 0$ & 25 & معنوي & 0.000 & $.667^{* *} 0$ & 8 \\
\hline معنوي & 0.000 & $.606^{* *} 0$ & 26 & معنوي & 0.000 & $.666^{* *} 0$ & 9 \\
\hline معنوي & 0.000 & $.669^{* *} 0$ & 27 & معنوي & 0.004 & $.386^{* *} 0$ & 10 \\
\hline معنوي & 0.000 & $.651^{* * *} 0$ & 28 & معنوي & 0.000 & $.515^{* *} 0$ & 11 \\
\hline معنوي & 0.000 & $.654^{* * *} 0$ & 29 & معنوي & 0.001 & $.441^{* *} 0$ & 12 \\
\hline معنوي & 0.000 & $.556^{* * *} 0$ & 30 & معنوي & 0.007 & $.361^{* *} 0$ & 13 \\
\hline معنوي & 0.000 & $.531^{* * *} 0$ & 31 & معنوي & 0.004 & $.381^{* *} 0$ & 14 \\
\hline معنوي & 0.000 & $.528^{* * *} 0$ & 32 & معنوي & 0.000 & $.514^{* *} 0$ & 15 \\
\hline معنوي & 0.001 & $.425^{* * *} 0$ & 33 & معنوي & 0.000 & $.614^{* *} 0$ & 16 \\
\hline معنوي & 0.000 & $.529^{* *} 0$ & 34 & معنوي & 0.000 & $.706^{* *} 0$ & 17 \\
\hline
\end{tabular}

قيمة الدلالة تكون معنوية إذا كانت > من 0.05، ونجد أن جميع فقرات المقياس دالة احصائياً عند مستوى دلالة (0.05) 


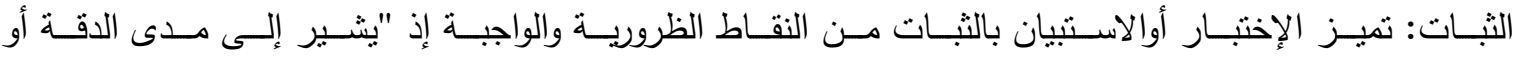

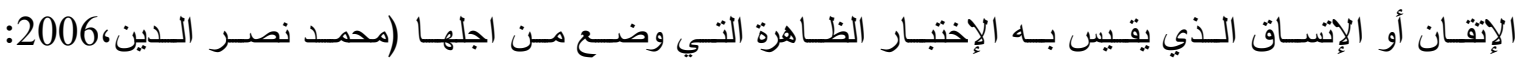
ص98)، وللتحقق من ثبات الاستبانه أستخدمت الباحثة الطرائق الأتية: طريقـة التجزئـة النصـفية: قســت الباحثة فقرات الاستبيان إلى نصـفين نصـف أول ونصـف ثناني وتـم إسـتخراج

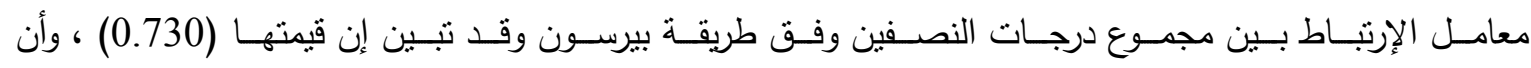
معامـل الإزتبـاط هنــا يثـير إلـى ثبـات نصـف الاسـتبيان ومـن ثـم الثبـات الكامـل وفـق معادلــة سـبيرمان بـراون لتصحيح الثبات ليكون الثبات الكلي (0.755)

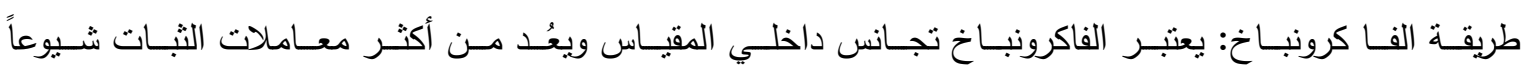

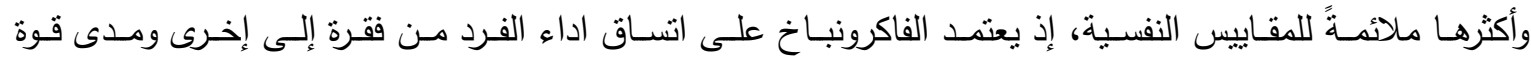

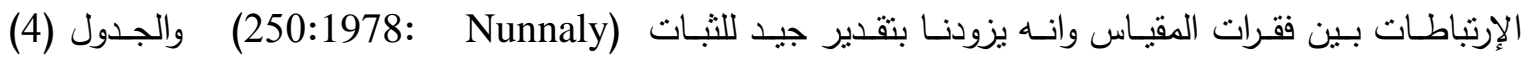
يبين معامل الثبات من خلال التجزئة النصفية والفاكرونباخ للاستنيان. الجدول (4) يبين معاملات الثبات للاستبيان

\begin{tabular}{|c|c|c|c|}
\hline \multirow{2}{*}{ الفا كرونباخ } & \multicolumn{2}{|c|}{ التجزئة النصفية } & \multirow{2}{*}{ المقاييس } \\
\hline & معامل الثبات & ثبات نصف الاختبار & \\
\hline 0.777 & 0.755 & 0.730 & التحليل الاستراتيجي \\
\hline
\end{tabular}

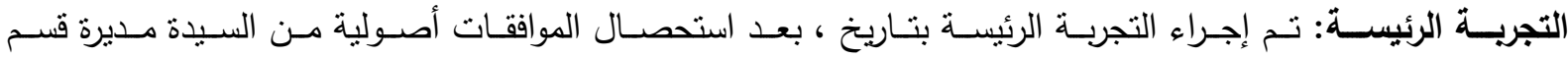

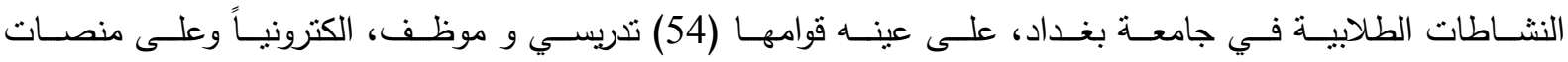

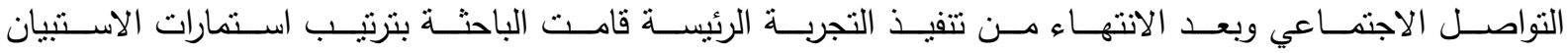

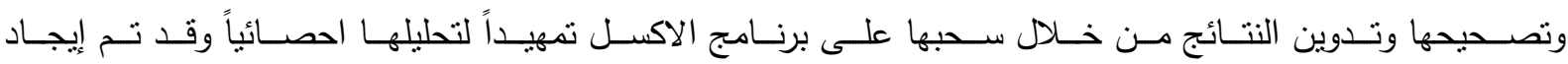

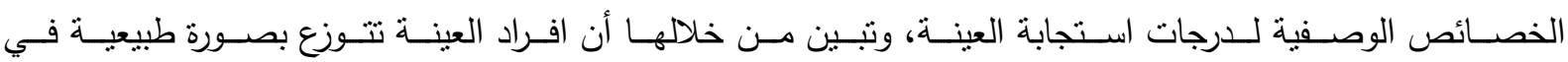
الاستبانه. الوسـائل الإحصــائية: اسـتعمل الباحـث الحقيــة الإحصـائية (SPSS) لمعالجـة نتـائج البحــث عبـر القـوانين الآتيـة: (الوســ الحسـابي، الاتحـراف المعيـاري، الخطـأ المعيـاري، معامـل الالتـواء، اختبـار (ت) للعينـات المسـتقلة، معامـل الارتباط بيرسون، معامل الارتباط سبيرمان،الوسط الفرضي).. 


\begin{tabular}{|c|c|c|}
\hline الوصليلة للاستبانه & الخصائص (J) بيين الحصال & $ت$ \\
\hline 98.7037 & الوسط الحسابي & 1 \\
\hline 28.18111 & الانحراف المعياري & 2 \\
\hline 0.035 & الالتواء & 3 \\
\hline 0.325 & الخطأ المعياري & 4 \\
\hline 34.00 & اقل درجة & 5 \\
\hline 170.00 & اعلى درجة & 6 \\
\hline
\end{tabular}

الجدول (6) يبين الوسط الحسابي والانحراف المعياري وقيمة (T) والوسط الفرضي للاستنيان

\begin{tabular}{|c|c|c|c|c|c|c|c|c|c|}
\hline أعلى & درجة & الدلالة & الخطأ & قيمة T & الفرضي الوسط & الانحراف المعياري & الحسابي & الاسنبانه & عدد \\
\hline 170 & 34 & 0.000 & 0.325 & 37.414 & 102 & 28.18111 & 98.7037 & الاستراتيجي التحليل & 54 \\
\hline
\end{tabular}

الجدول (7) يبين الفروق بين الكليات العلمية و الكليات الانسانية

\begin{tabular}{|c|c|c|c|c|c|c|}
\hline النتيجة & قيمة الدلالة & القيمة (T) & الانحراف المعباري & الوسط الحسابي & عدد العينة & تخصص الكليه \\
\hline \multirow{2}{*}{ معنوي } & \multirow{2}{*}{0.010} & \multirow{2}{*}{2.871} & 12.93089 & 107.0500 & 34 & علمية \\
\hline & & & 26.95220 & 92.0000 & 20 & انسانية \\
\hline
\end{tabular}

المناقشة:

يتبـين مـن جدول (6) وبعـد المقارنـة بـين الوسـط الفرضـي و الوسـط الحسـابي للاسـتبانه تبـين لنـا هنـاك فـروف معنويـة ولصـالح الوســ الفرضـي، إذ يـدل ذلــك إلـى إن درس الانشـة الرياضـية يعـاني مـن مشـكلات عـدة

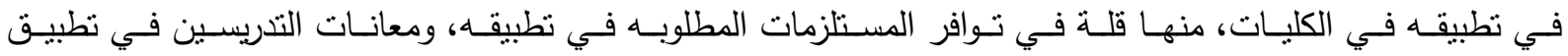
درس الانثـطة الرياضـية ضــن جـدول الـدروس الأسـبوعي وتفضـيل الــروس المـواد الأخـرى بسـبب زخـم المقـررات

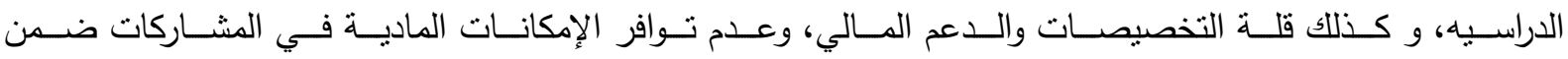
المنافسـات في بطـولات الجامعـه، او المشــاركه بشـكل رمـزي حسـب قدرات الكليـه وإكاناتهـا الخاصــة ، وهـذا يـؤثر سـلبياً في تنفيذ وتطوير واقـع الانشـة الرياضـية في الكليـة بشكل خـاص و الجامعـه بشكل عـام، وبالتـالي يـعكس بثـكل سـلبي علىى اسـتمالة الطلبـة نحـو الممارسـة الفعليـة فـي الانثـطة الرياضـية، بـالرغم مـن إن درس الانثـطه

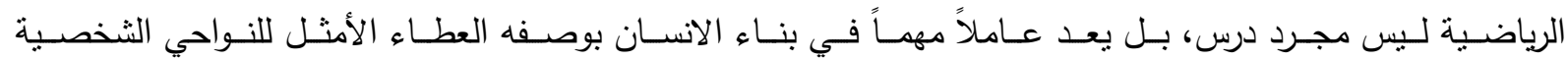

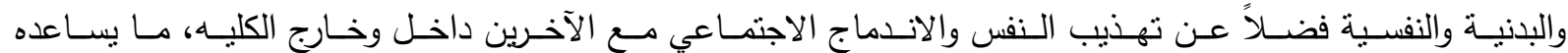




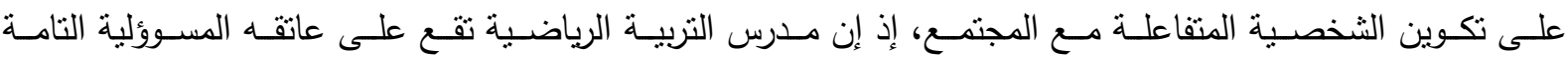

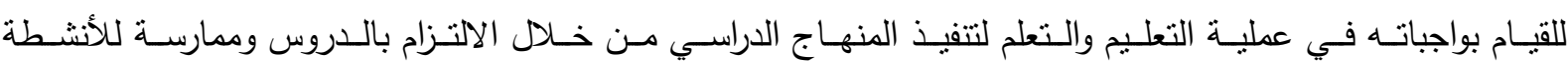
الرياضية على المستوى الصفي واللاصفي حسب القابليات والفروق الفردية (ثامر حماد: 2018: 10). ويتبـين مـن الجـدول (7) وبعـــ المقارنـهـ بـين الاسـاط الحسـابية للكليـات العلميـة و الانسـانية، تبـين ان هنـاك فـروق ذات دلالــة احصـائية و لصـالح الكليـات العلميـة، وتعـزو الباحثـة نلـك الفـروق الـى إن تطبيـق درس الانثـطة

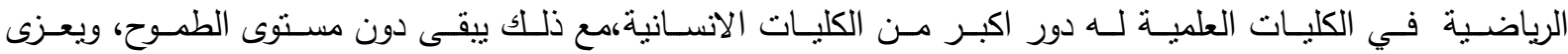

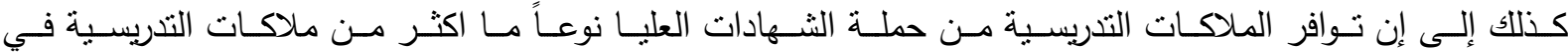

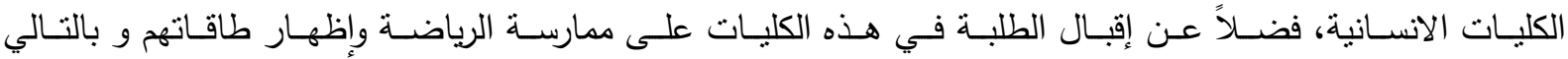

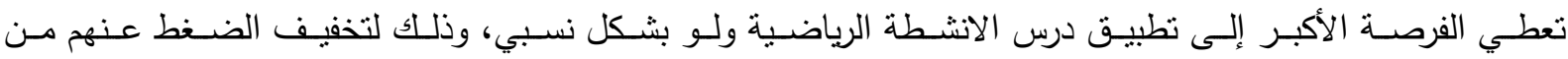

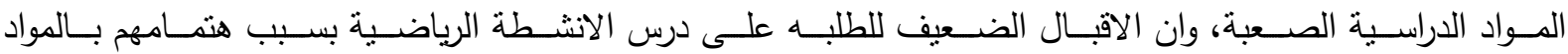

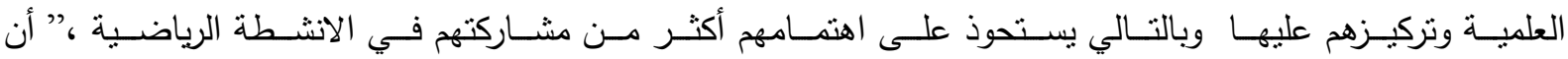

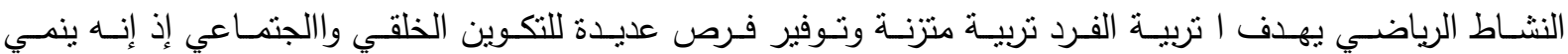

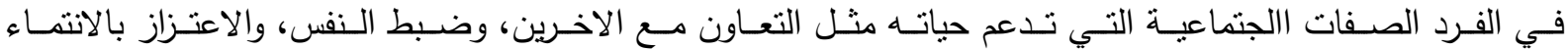

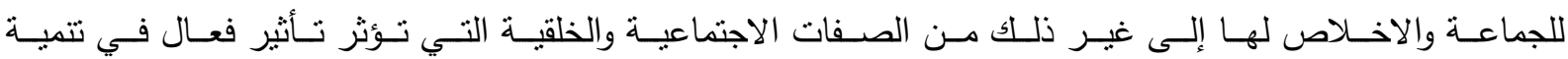

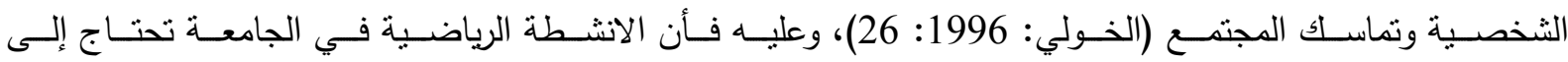
وضـع إسـتراتيجية مخطط لهـا مسـبقا الهـدف منهـا النهوض بالانثـطة الرياضـية، وكذللك على ضـرورة البحـث عـن أفضـل البـدائل لتحقيـق كـل هـدف في مـدة معلومـة في حـدود الامكانـات والظـروف المتاحسة وتحقيـق أفضـل النتـائج

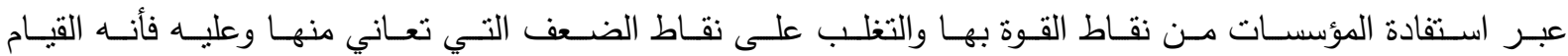

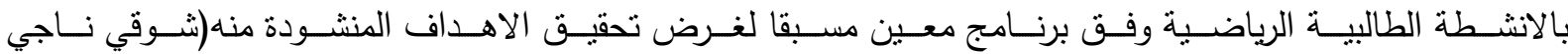

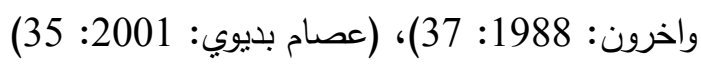

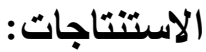

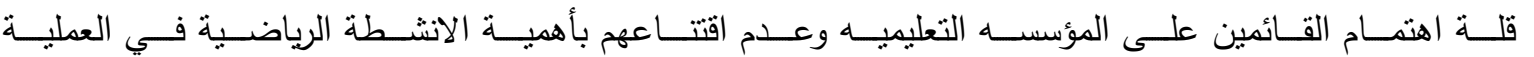

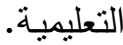

هناك معوقات ادارية تعيق الطلبه من المشاركة بالانشطة الرياضية. ضعف تطبيق درس الانشطة الرياضية في كليات الجامعه. تباتين الفروق بين الكليات العلمية و الكليات الانسانية ولصاح الكليات الانسانية. الظروف الصحية الحالية وتأثثراتها على استحالة إقامة درس التربية الرياضية.

ضرورة تشجيع الطلبه للمشاركة بالانشطة الرياضية.

زيادة التخصيصات المالية لتوفير مستلزمات النشاط الرياضي من قبل الجامعة. نشر نقافة الرياضة الحامعية بين الطلبة من خلال اقامة دورات ارشادية لتطوير الرياضة الجامعية تطوير وتتويع الانشطة الرياضية لتواكب التطورات المستمرة فيها. تطبيق المقياس على جامعات أخرى لمعرفة سير عمل النشاطات الطلابية فيها ومقارنتها مع جامعة بغداد. 
المصادر

أمـــن أنـور الخـولي، (1996). الرياضــة والمجتمع، سلســلة عـالم المعرفـة، العـدـ 216 ،المجلـس الـوطني للتقافة والفنون والاداب، الكويت.

ثـامر حمــاد رجـه، (2018) دراســة التحليـل الاسـتراتيجي كـليل عهـل تقـويم درس التربيـة الرياضــة للهــارس المتوسطة في تربية بغداد الرصافة، مجلة علوم الرياضة، مج 11، عدد 38. شوقي ناجي وآخرون، (1988). مبادئ الادارة: بغداد، مؤسسة المعاهد الفنية.

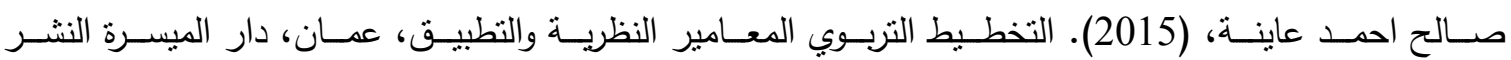
والتوزيع.

ظـافر هاثتـم الكـاظمي، (2012). التطبيقـات العلميـة لكتابــة الرســائل والاطــاريح التربويــة والنفسـية، جامعــة بغداد،كلية التربية الرياضية. عصــام بـدوي، (2001). موسـوعة التتظـيم والادارة فـي التربيــة البدنيـة والرياضـية، ط1 ،دار الفكـر العربـي،

$$
\text { علي فهي البيك ، (1993) ـ تخطيط التدريب الرياضي ، منشاءة المعارف الاسكندرية. }
$$$$
\text { قاسم حسن حسين واخرون ، (1979). نظريات التربية الرياضية ، مطبعة جامعة بغداد ، بغداد . }
$$

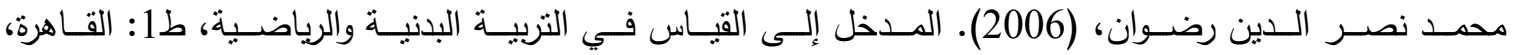
مركز الكتاب للنشر . n

مفتــي ابـراهيم حدـاد ، (1999). نطبيقـات الادارة الرياضــية - المــدارس والجامعــات - الاتحــادات الرياضـية - الاندية الرياضية - مراكز الثباب ، مركز الكتاب للنشر، الطبعة الاولى

Jerry R. Thomas and Jack K. Nelson: (1996)Research Methods In Physical Activity, 3ed Edition, USA, Human Kinitics,.

Moosavi, S. J., Habibian, M \& Safania, A. M. (2012). IR Iran wrestling strategy specifying, determining and analyzing strengths, weaknesses, opportunities and threats (SWOT .(IRJABS Journal.1778-1769.(9)3

Nunnaly , J.C. ; Psychometric Theory :(1978) 2nded : New York, Ms. Graw - hill 
الملاحق

استبانه التحليل الاستراتيجي

\begin{tabular}{|c|c|c|c|c|c|c|}
\hline تنطبق بلرجة & تنطبق بلرجة & تنطبق بلرجة & تنطبق بدرجة & تنطبق بدرجة & الفقرات & $ت$ \\
\hline & & & & & تما يتناسب مع الإعداد الكافية من مدرسي التربية الرياضية & 1 \\
\hline & & & & & توافر وسائل تقويمية لمعرفة مدى نجاح تطبيق & 2 \\
\hline & & & & & الكلية لتنفيذ درس التربية الرياضية. الفضاءات المتروكة في & 3 \\
\hline & & & & & سنويا. تخصيص تجهيزات رياضية شخصية للتريسي & 4 \\
\hline & & & & & توالبرافر ت تخصيصات مالية ت تغطي ممارسة الألعاب & 5 \\
\hline & & & & & تلتعاون عمادة الكلية لتفعيل درس التربية & 6 \\
\hline & & & & & واللياقة البلنية لاى الطلبة كافية من التدريبات لتنمية عناصر & 7 \\
\hline & & & & & البنين والبنات في الألعاب الرياضي الفروق الفردية بين & 8 \\
\hline & & & & & المهارات للألعاب الرياضية الإيضاح الحديثة في ت & 9 \\
\hline & & & & & علدم وضع الخطط الكفيلة لإنجاح تطبيق المنهاج & 10 \\
\hline & & & & & والصفوف. إنتوفر إنية التعامل مع كثرة أعداد الطبة & 11 \\
\hline & & & & & مفردات المنهاج الرياضي العمراني للكلية بما لا يلاءم تنفيذ & 12 \\
\hline & & & & & 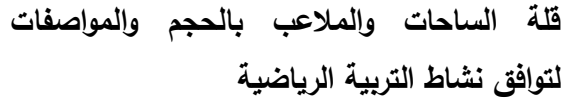 & 13 \\
\hline & & & & & 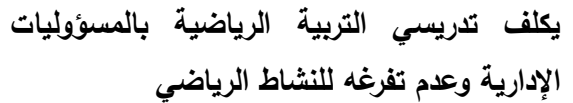 & 14 \\
\hline & & & & & لا لا تتوفر النماذج الخاصة بالعروض الرياضية بما & 15 \\
\hline & & & & & من الجدول الأسبوعي. & 16 \\
\hline & & & & & ويراعي تدريسي التربية الرياضية طبيعة الأعراف & 17 \\
\hline & & & & & فتوف الكليات الأخرى. & 18 \\
\hline
\end{tabular}




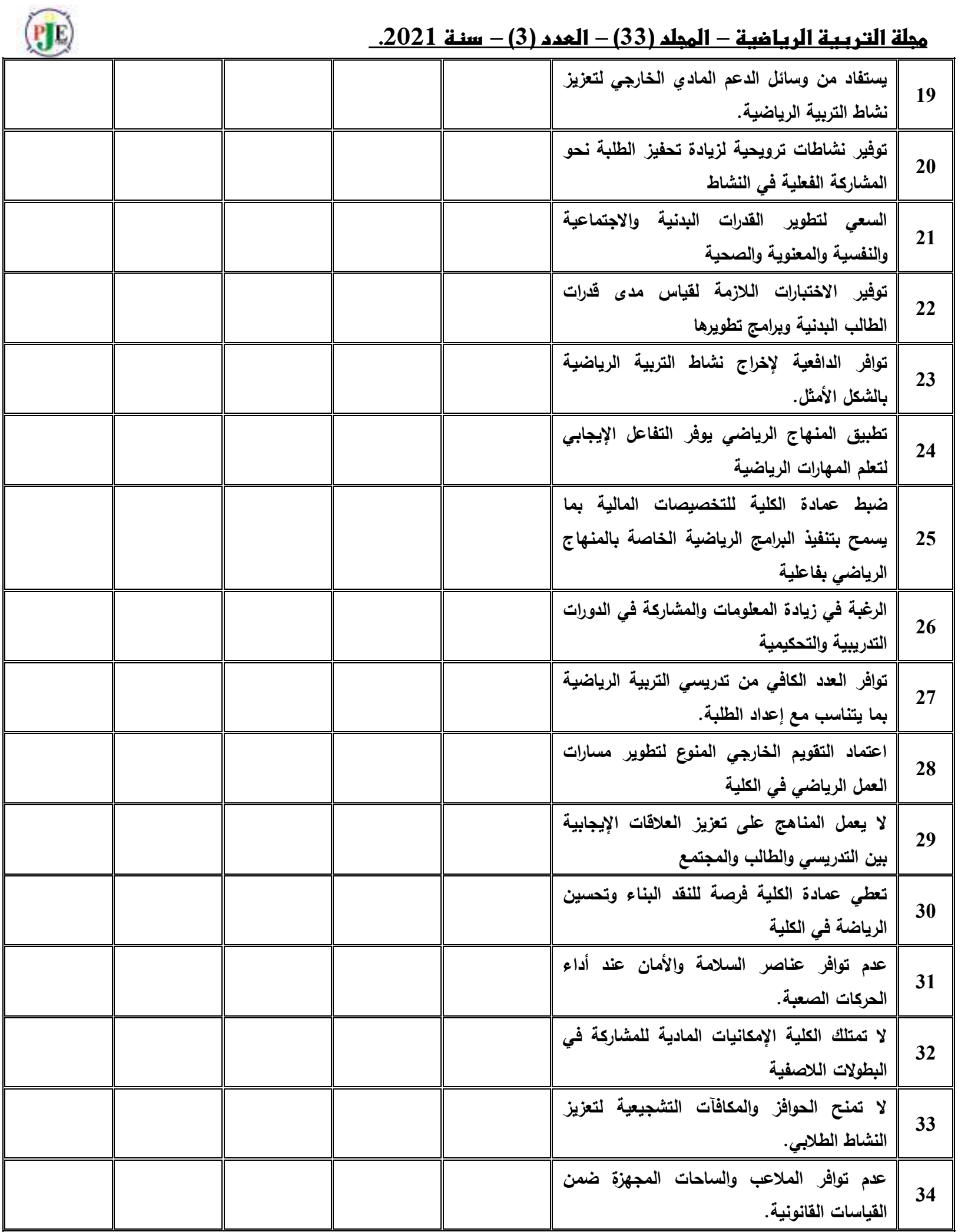

